\title{
STRUKTUR VERTIKAL DAN VARIABILITAS ARLINDO YANG MASUK KE TEPI BARAT LAUT BANDA
}

\section{VERTICAL SRUCTURE AND VARIABILITY OF INDONESIAN THROUGHFLOW (ITF) IN TO WESTERN BANDA SEA}

\author{
La Ode M. Gunawan Giu*1, Agus S. Atmadipoera ${ }^{2}$, \\ Yuli Naulita ${ }^{2}$, \& Dwiyoga Nugroho 3 \\ ${ }^{1}$ Program Studi Ilmu Kelautan, Sekolah Pascasarjana, IPB University, Bogor, 16680, Indonesia \\ ${ }^{2}$ Departemen Ilmu dan Teknologi Kelautan, FPIK, IPB University, Bogor, 16680, Indonesia \\ ${ }^{3}$ Badan Riset Kelautan dan Perikanan, KKP, Jakarta Utara, 14430, Indonesia \\ E-mail: gunawan.log@gmail.com
}

\begin{abstract}
The Indonesian Throughflow (ITF) is an inter-ocean Pacific-Indian current system that passes Indonesian Seas, such as via the primary path of Makassar Strait to Flores Sea and via the secondary path of Lifamatola Strait to Banda Sea. This study aims to investigate the structure and volume transport estimate of ITF Eastern Flores Sea (Flores) and Northern Banda Sea (Banda) derived from ocean model output of INDESO between 2008 and 2014. Structure of the ITF is analyzied by the average of current component vertically and transport volume estimated by cross-section at Banda and Flores sea. Time-series variability of ITF is analyzed using band-pass filter and continuous wavelet transforms. The results showed that ITF Banda was characterized by flow dominantly towards south while ITF Flores depicted was flowing east along the North of Nusa Tenggara Islands. The vertical structure of ITF flow is intensified at a depth between $50 \mathrm{~m}$ and $150 \mathrm{~m}$. The total volume transport estimate over the 7-year period from both ITF paths into the western Banda Sea is about $6.27 \mathrm{~Sv}( \pm 3.81 \mathrm{~Sv})$, which is a good agreement with previous model studies. Variations of transports ITF in Banda (Flores) is maximum during northwest (southeast) monsoon and minimum during southeast (northwest) monsoon. The variability of the ITF Banda is dominated intra-seasonal (ISV) and semi-annual periods (SAV), while the ITF Flores is annual period (AV).
\end{abstract}

Keywords: Banda Sea, Flores Sea, Indonesian throughflow, stucture vertical of ITF

\begin{abstract}
ABSTRAK
Arus Lintas Indonesia (Arlindo) merupakan sistem arus antara Samudra Pasifik dan Hindia yang melewati Laut Indonesia, seperti melalui jalur primer Selat Makassar ke Laut Flores dan melalui jalur sekunder Selat Lifamatola ke Laut Banda. Penelitian ini bertujuan untuk mengkaji struktur vertikal dan variabilitas Arlindo di Laut Flores Timur (Flores) dan Laut Banda Utara (Banda) yang berasal dari keluaran model laut INDESO antara tahun 2008 dan 2014. Analisis struktur Arlindo dengan menghitung rataan komponen arus secara vertikal. Volume transpor dihitung dari penampang di Laut Banda dan Laut Flores. Deret waktu Arlindo dianalisis variabilitasnya menggunakan filter band-pass dan transformasi wavelet kontinu. Hasil penelitian menunjukkan bahwa Arlindo Banda secara dominan mengalir ke selatan, sedangkan Arlindo Flores mengalir ke timur di sepanjang utara Kepulauan Nusa Tenggara. Struktur vertikal aliran Arlindo mengalami penguatan di kedalaman antara $50 \mathrm{~m}$ dan $150 \mathrm{~m}$. Perkiraan total volume transpor selama periode 7 tahun dari kedua jalur Arlindo yang masuk ke Laut Banda bagian barat sebesar $6,27 \mathrm{~Sv}( \pm 3,81 \mathrm{~Sv})$, yang merupakan kesepakatan baik dengan studi model sebelumnya. Variasi tahunan transpor Arlindo Banda (Flores) maksimum selama musim Barat Laut (Tenggara) dan minimum selama musim Tenggara (Barat Laut). Variabilitas yang mendominasi pada transpor Arlindo Banda ialah periode intra-musiman (ISV) dan semi-tahunan (SAV), sedangkan variabilitas transpor Arlindo Flores didominasi oleh periode tahunan (AV).
\end{abstract}

Kata kunci: Arlindo, Laut Banda, Laut Flores, struktur vertikal Arlindo 


\section{PENDAHULUAN}

Laut Banda merupakan perairan berbentuk cekungan (basin) terbesar dan terdalam di Laut Indonesia (Figure 1). Perairan ini menjadi jalur dari arus utama berupa Arus Lintas Indonesia (Arlindo) dan arus musiman yang terjadi dua kali dalam setahun (Hutahaen \& Wilson, 1992; Gordon, 2005). Arlindo merupakan aliran massa air dilapisan termoklin yang bergerak dari Samudra Pasifik menuju Samudra Hindia akibat adanya perbedaan tinggi paras laut (rerata $\pm 20 \mathrm{~cm}$ ) antar kedua Samudra (Fieux et al., 1994; Mayer et al., 2010). Perbedaan tinggi paras laut ini berdampak pada volume angkutan (transpor) Arlindo antara yang masuk dan keluar menuju Samudra Hindia, yang mana pada periode musim Tenggara mencapai maksimum dan minimum pada musim Barat Laut (Gordon \& Susanto, 2001; Sprintall et al., 2009). Menurut Sukresno \& Kasa (2008) bahwa perairan Laut Banda memiliki perbedaan sirkulasi antara dua sisi, diantaranya sisi timur perairan dipengaruhi oleh variasi munson sementara sisi barat dipengaruhi oleh Arlindo.

Arlindo memasuki perairan Indonesia melalui dua jalur yakni jalur barat, transpornya sebesar $80 \%$ melalui Laut Sulawesi menuju Selat Makasar, selanjutnya aliran ke Selatan dan bercabang dengan satu cabang menuju Samudra Hindia melalui Selat Lombok dan sisanya 50\% mengalir ke Laut Flores dan Laut Banda. Berikutnya, dari jalur timur sebesar $20 \%$ melalui Laut Halmahera dan Laut Maluku menuju Laut Seram melalui Pintasan Lifamatola dan mengalir ke Laut Banda (Atmadipoera et al., 2009; Gordon et al., 2010). Saat ini, estimasi tranpor Arlindo telah banyak dilakukan baik dari data observasi langsung maupun data asimilasi model. Program International Nusantara Stratification and Transport (INSTAN) yang dilakukan dari tahun 20042006, menunjukkan transpor Arlindo mengalir dari jalur utama Selat Makassar sebesar 11,6 Sv $\left(1 \mathrm{~Sv}=10^{6} \mathrm{~m}^{3} \mathrm{~s}^{-1}\right)$ (Gordon et al., 2010) dan jalur timur melalui Pintasan Lifamatola sebesar 2,5 Sv (Van Aken et al., 2009), total transpor Arlindo sebesar $15 \mathrm{~Sv}$ (Sprintall et al., 2009; Gordon et al., 2010). Menurut Syamsudin et al. (2010) sekitar 5 Sv Arlindo dari jalur barat mengalir ke Laut Flores dan secara keseluruhan sekitar $10 \mathrm{~Sv}$ Arlindo transit di Laut Banda (Gordon \& Fine, 1996) sebelum keluar menuju Samudra Hindia melalui Selat Ombai dan Pintasan Timor (Sprintall et al., 2009).

Transpor Arlindo berpengaruh terhadap variabilitas iklim dalam rentang skalawaktu yang luas, misalnya dari waktu intramusiman, musiman hingga antar tahunan (Iskandar et al., 2014). Pada skala waktu intra-musiman, fluktuasi Arlindo berhubungan erat dengan dinamika laut-atmosfer di wilayah ekuator seperti kedatangan gelombang Kelvin Hindia dan Rossby Pasifik (Wijffels \& Meyers, 2004; Syamsudin et al., 2010). Gelombang kelvin berasal dari ekuator Samudra Hindia, dalam penjalarannya gelombang ini terperangkap di area pantai (coastally trapped Kelvin waves) timur Samudra Hindia selama satu bulan dan bergerak menyusuri area barat Sumatra hingga selatan Jawa, sebagian masuk ke Selat Lombok dan bergerak ke Selat Makassar (Sprintall et al., 2000), sebagian lainnya menjalar ke timur pulau Nusa Tenggara hingga mencapai Laut Banda melalui Selat Ombai dan Pintasan Timor (Sprintall et al., 2009; Syamsudin et al., 2010). Berikutnya gelombang Rossby dari Samudra Pasifik yang merambat ke tepi barat Papua New Guinea dan masuk ke Laut Banda sebelum keluar ke Samudra Hindia melalui Laut Timor (Sprintall et al., 2009; Masoleh et al., 2019. Pada skala-waktu musiman terkait dengan perubahan arah arus, akibat dari muson Tenggara dan muson Barat Laut (Gordon \& Susanto, 2001). Pada skala-waktu antar-tahunan, Arlindo dipengaruhi oleh dinamika interaksi lautatmosfer di Samudra Pasifik dan Hindia, seperti fenomena El-Nino Southern Oscillation (ENSO) dan Indian Ocean 
Dipole (Gordon, 2005; Sukresno \& Kasa, 2008; Shinoda et al., 2012).

Dinamika perairan yang terjadi di Laut Banda dapat memberikan pengaruh terhadap estimasi transpor Arlindo antara yang masuk dan keluar menuju Samudra Hindia. Penelitian mengenai Arlindo sejauh ini telah banyak dilakukan, namun masih sedikit kajian spesifik yang dilakukan di Laut Banda padahal $80 \%$ jalur Arlindo baik dari pintu barat maupun timur melintasi Laut Banda (Liang et al., 2019). Dengan demikian, tujuan dari penelitian ini adalah untuk mengkaji struktur vertikal dan variabilitas Arlindo yang mengalir ke tepi barat Laut Banda. Hipotesis dalam penelitian ini bahwa volume transpor Arlindo lebih besar dari jalur barat yang melewati Laut Flores dibanding jalur timur (Laut Banda Utara).

\section{METODE PENELITIAN}

\subsection{Waktu dan Lokasi Penelitian}

Penelitian ini difokuskan di Laut Banda bagian Utara termasuk Laut Flores dengan batasan area (kotak merah) 1,6 ${ }^{\circ}$ - $8,5^{\circ} \mathrm{LS}$ dan $121^{\circ}-126^{\circ} \mathrm{BT}$ (Figure 1). Data deret waktu (time-series) yang digunakan bersumber dari data keluaran model Infrastructure Development for Space Oceanography (INDESO) dengan rentang waktu pada Januari 2008 sampai Desember 2014 (7 tahun). Validasi data dalam penelitian ini menggunakan data sea level anomaly (anomali tinggi paras laut) antara hasil model dan satelit, sehingga dibuatkan sampling box (kotak merah arsir) untuk memperoleh korelasi dari data tersebut. Analisis data deret waktu dari komponen arus Arlindo dibuatkan transek, mewakili jalur timur yakni Banda Utara (Arlindo Banda) pada transek A-B di lintang $3,32^{\circ} \mathrm{LS}$ dan mewakili jalur barat melewati Laut Flores bagian timur (Arlindo Flores) pada transek C-D di bujur $122,7^{\circ} \mathrm{BT}$. Nilai dari transek akan dibuat rataan spasial untuk analisis lebih lanjut.

\subsection{Bahan dan Sumber Data}

Data penelitian yang digunakan merupakan data deret-waktu yang bersumber dari hasil keluaran simulasi model 3-dimensi

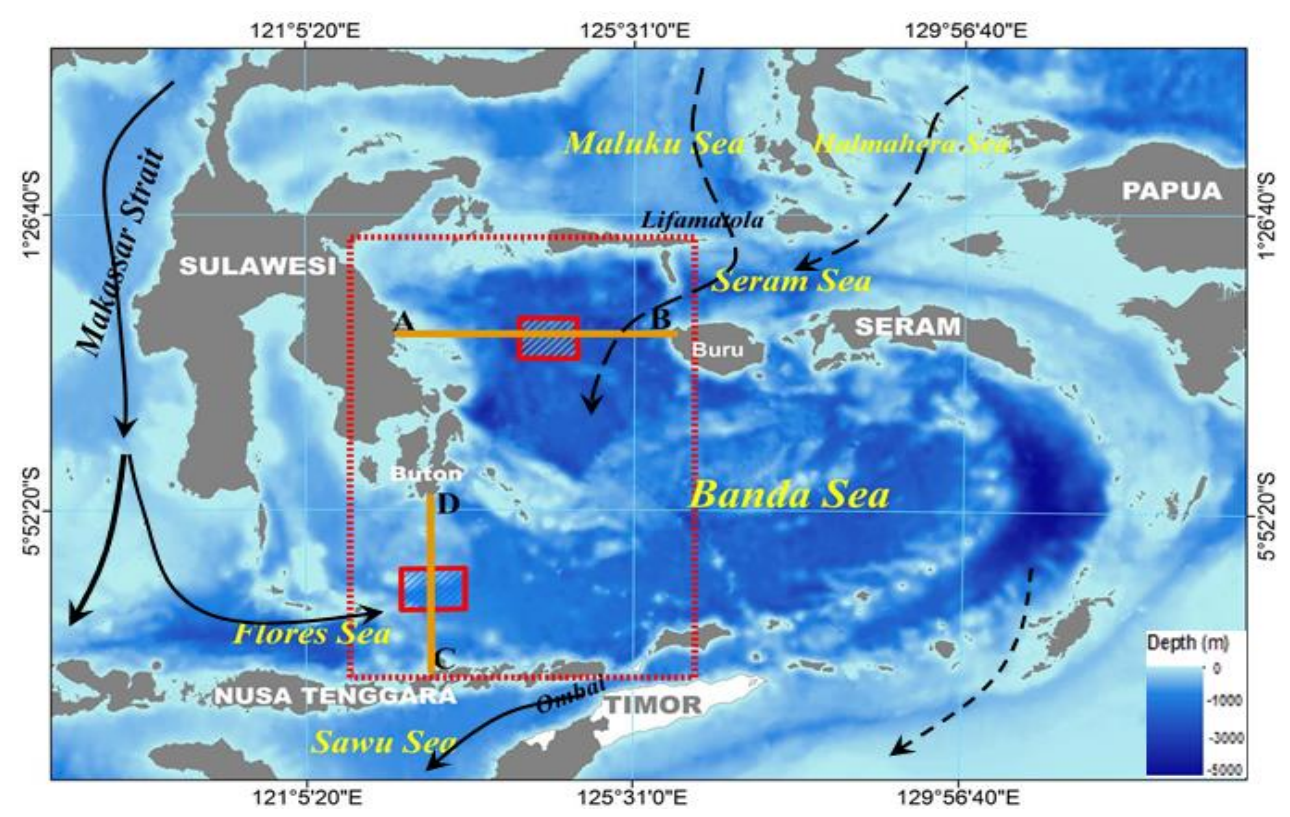

Figure 1. Circulation scheme of ITF (black arrow) in the study area on the western Banda Sea. Transects of $A-B$ and $C-D$ for calculation of ITF transport volume via North Banda and East Flores. Two red shading boxes are Sampling Boxes for validation between model and satellite time-series data. 
sirkulasi laut INDESO tahun 2008-2014. Konfigurasi model INDESO telah dideskripsikan secara detail oleh Tranchant et al. (2016). Data ini memiliki keluaran berupa data arus komponen zonal $(u)$ dan meridional $(v)$, suhu, salinitas, dan tinggi paras laut dengan rentang waktu data dari tanggal 1 Januari 2008 sampai 31 Desember 2014. Data model mempunyai resolusi grid horizontal $1 / 12^{\circ}$ atau $9,25 \mathrm{~km}$ dan resolusi vertikal mencapai 50 level kedalaman.

Data validasi dalam penelitian ini menggunakan data anomali Tinggi Paras Laut (TPL). Perbedaan TPL merupakan salah satu penyebab terjadinya pergerakan arus sehingga perlu dilakukan validasi dengan hasil model INDESO. Data TPL bersumber dari satelit altimetri Jason 2 yang diluncurkan sejak tahun 2008 setelah satelit TOPEX/Poseidon dan Jason-1 berakhir. Data TPL yang diperoleh merupakan rataan harian selama 7 tahun dari tahun 2008-2014, diunduh dari situs web (website) http://marine.copernicus.eu/satellite-

altimetry-ocean-circulation/. Data ini memiliki resolusi spasial $1 / 4^{\circ}$ atau $27,78 \mathrm{~km}$ dan resolusi temporal 1 hari.

\subsection{Pengolahan Data dan Analisis Data} Data hasil simulasi model INDESO (2008-2014) divalidasi terlebih dahulu dengan menentukan tingkat akurasi dari data satelit. Pengolahan data arus pada penelitian ini menggunakan perangkat lunak Ubuntu Pyferret untuk komputasi, visualisasi, dan analisis. Sedangkan, variabilitas arus menggunakan analisis Continous Wavelet Transform (CWT) dan Power spectral density (PSD) melalui perangkat Mathlab.

Karakteristik dan variabilitas arus di wilayah studi dikaji melalui analisis data deret-waktu (2008-2014), dengan menghitung nilai rataan arus zonal dan meridional secara vertikal pada kedalaman 0-500 m. Transpor massa air Arlindo $(Q v)$ yang mengalir di Laut Banda bagian Utara yang melewati transek garis A-B pada $122,68^{\circ} \mathrm{BT}-125,93^{\circ} \mathrm{BT}$ dan $3,32^{\circ} \mathrm{LS}$, dan
Arlindo ( $Q u)$ yang melewati Laut Flores ditransek pada C-D $8,3^{\circ} \mathrm{LS}-5,75^{\circ} \mathrm{LS}$ dan $122,7^{\circ} \mathrm{BT}$ dapat dihitung dengan mengintegralkan kecepatan arus komponen zonal (u) atau meridional (v) terhadap panjang transek dan kedalaman, yang dimodifikasi dari Emery \& Thomson, (2014):

$\mathrm{Q} v_{\mathrm{A}-\mathrm{B}}=\int_{A}^{B} \int_{z}^{0} v d x d z$

$\mathrm{Q} u \mathrm{C}-\mathrm{D}=\int_{D}^{C} \int_{z}^{0} u d y d z$

Keterangan: Qvu ialah besaran volume transpor Arlindo (1 Svedrup $=10^{6} \mathrm{~m}^{3} \mathrm{~s}^{-1}$ ) pada transek A-B dan C-D, dan $z$ ialah batas bawah $(1000 \mathrm{~m})$ secara vertikal hingga ke permukaan $(0 \mathrm{~m})$, serta $v$ dan $u$ komponen arus meridional (m/det ) dan zonal (m/det).

Selanjutnya, digunakan analisis CWT yang dapat merepresentasikan sinyal ke dalam fungsi frekuensi terhadap waktu, sehingga hasil akhir yang diperoleh dapat diketahui perubahan waktu dan frekuensi secara bersamaan dari suatu data deret waktu (Torrence \& Compo, 1998). Penggunaan analisis CWT untuk menganalisis periode yang dominan pada selang kepercayan $95 \%$. Metode CWT yang digunakan hasil dari Grinsted et al. (2004):

$\psi 0(\eta)=\pi^{-1 / 4} e^{-i \omega 0 n} e^{-1 / 2} \eta^{2}$

Keterangan: $\omega 0$ adalah bilangan gelombang yang tidak berdimensi dan $\eta$ adalah waktu yang tidak berdimensi. Nilai terbaik untuk $\omega 0$ adalah 6 untuk keseimbangan skala yang bagus antara jarak dan panjang gelombang (Quentel et al., 2010).

CWT dalam prosesnya mengaplikasikan wavelet sebagai band-pass filter terhadap data. Mother wavelet pada persamaan (4) merenggang dan merapat pada panjang gelombang dengan memvariasikan skalanya (s), sehingga $\eta=s . t$ dengan $t$ adalah waktu. Dengan interval waktu yang seragam sebesar $\delta t$, maka transformasi wavelet adalah konvolusi dari data waktu $x t$ dengan mother 
wavelet yang mengalami pergeseran dan kompresi diekspresikan sebagai berikut:

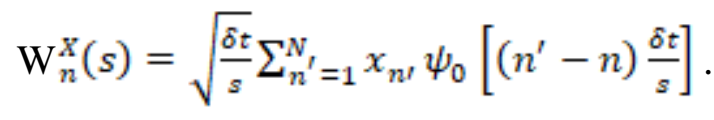

Keterangan: $\psi 0$ adalah frekuensi yang tidak berdimensi dimana saat menggunakan tujuannya untuk mengekstraksi mother wavelet.

Berikutnya untuk mengetahui nilai energi setiap sinyal dalam data deret-waktu pada frekuensi yang sama, maka dilakukan analisis cross-PSD (Power Spectral Density). Persamaan yang digunakan untuk menghitung energi densitas spektral komponen merujuk pada persamaan Bendat \& Piersol (2010):

$X\left(f_{k}\right)=h \sum_{t=0}^{n-1} \exp \left[-\frac{2 \pi k t}{N}\right]$

Keterangan: $X\left(f_{k}\right)$ merupakan data deret waktu, $f_{X}$ Frekuensi ke- $k$ dengan interval data selama 1 hari, dan $N$ adalah jumlah data.

Perhitungan signifikan-level dapat dilakukan dengan pemotongan (cut-of) data deret waktu dari transpor Arlindo Banda Utara dan Arlindo Flores. Panjang data (N) (sampling interval harian dari 1 Januari 2008 sampai 31 Desember 2014) ialah 2557, panjang segmen (segment-lenght) ialah 512, dihitung batas bawah dan atas sehingga membentuk 4 segmen. Selanjutnya dari 4 segmen, dihitung nilai level signifikan pada selang kepercayaan 95\%. Keluaran dari analisis ini terdiri dari kospektral energi, koherensi dan beda fase.

Kospektral energi menunjukkan besarnya energi fluktuasi pada periode yang sama antara kedua data deret waktu. Apabila terjadi fluktuasi Arlindo di Utara Banda dan sinyal arus merambat ke Laut Flores demikian sebaliknya, maka dapat dinyatakan keduanya akan menunjukkan koherensi (hubungan) yang kuat antara kedua variabel dengan nilai koherensi yang tinggi. Sementara, beda fase menunjukkan perbedaan selang waktu antar kedua variabel. Beda fase positif menunjukkan bahwa fluktuasi variabel 1 mendahului (lead) variabel 2, sedangkan beda fase negatif menunjukkan bahwa fluktuasi variabel 1 tertinggal (lagged) dari variabel 2 (Emery \& Thomson, 2014).

Kospektral energi $\left(\mathrm{G}_{x y}\left(f_{k}\right)\right)$ dihitung dari dua pasang komponen fourier dari data deret waktu $x_{n}$ dan $y_{n}$ yang diukur dalam setiap selang waktu $\Delta t$ dengan menggunakan rumus (Bendat \& Piersol, 2010):

$$
G_{x y}\left(f_{k}\right)=\frac{2 \Delta t}{T}\left|X\left(f_{k}\right) * Y\left(f_{k}\right)\right|
$$

Keterangan: $X\left(f_{k}\right)$ merupakan komponen fourier dari $X n$, dan $Y\left(f_{k}\right)$ komponen fourier dari $Y_{n}$ serta $T$ ialah periode data.

Berikutnya, menghitung fungsi koherensi dengan menggunakan persamaan (Bendet \& Piersol, 2010);

$\gamma_{x y}^{2}\left(f_{k}\right)=\left|\frac{G_{x y}\left(f_{k}\right)^{2}}{s_{x}\left(f_{k}\right) s_{y}\left(f_{k}\right)}\right|$

Keterangan: $S_{x}\left(f_{k}\right)$ merupakan densitas energi $X\left(f_{k}\right)$ dan $S_{y}\left(f_{k}\right)$ adalah densitas energi $Y\left(f_{\mathrm{k}}\right)$.

Nilai beda fase $\left(\theta_{x y}\left(f_{k}\right)\right)$ dihitung menggunakan persamaan (Bendat \& Piersol, 2010):

$\left(\theta_{x y}\left(f_{k}\right)=\tan ^{-1}\left[\frac{Q_{x y}\left(f_{k}\right)}{c_{x y}\left(f_{k}\right)}\right]\right.$

Keterangan: $Q_{x y}\left(f_{k}\right)$ merupakan nilai imajiner dari $G_{x y}\left(f_{k}\right)$ dan $C_{x y}\left(f_{k}\right)$ adalah nilai nyata dari $G_{x y}\left(f_{k}\right)$.

\subsection{Validasi Data Hasil Model INDESO dan Data Observasi Satelit}

Validasi data model INDESO dilakukan dengan membandingkan hasil keluaran model berupa tinggi muka laut dengan data tinggi muka laut dari satelit altimetri. Hal ini bertujuan untuk menguji tingkat akurasi dan keterkaitan hasil keluaran model dengan pengukuran real-time dari satelit. Validasi 
a)

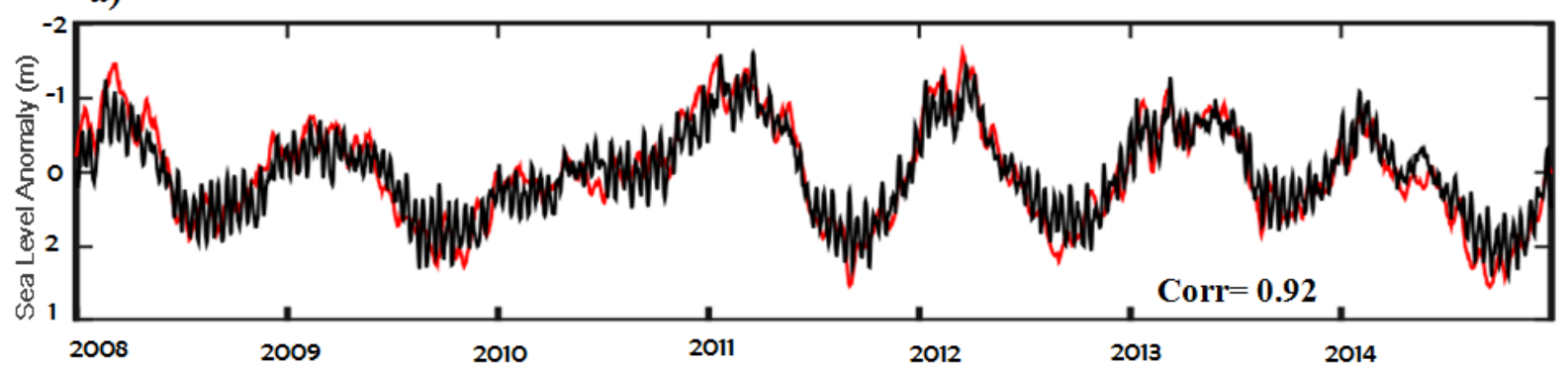

b)

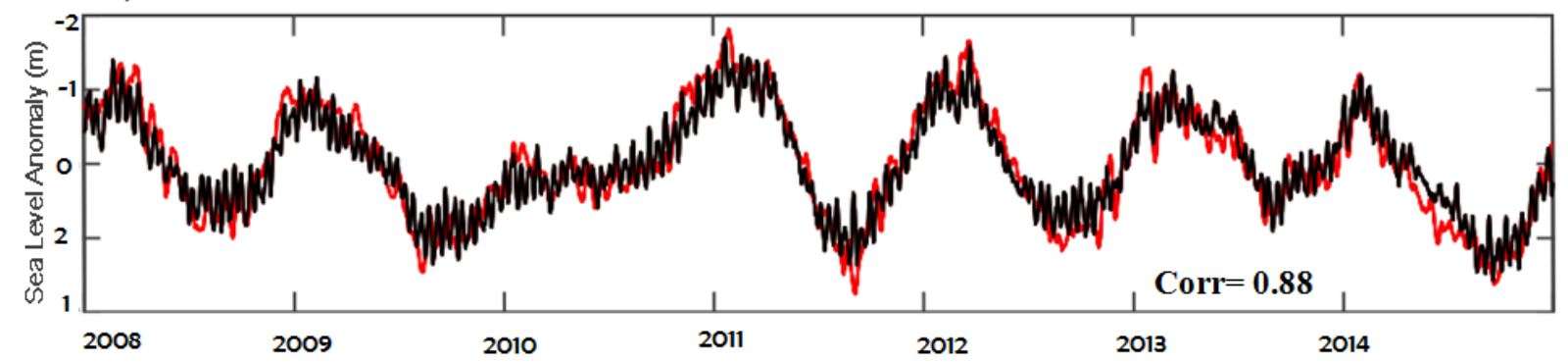

Figure 2. Comparison of 2008-2014 sea level anomaly time series data from the INDESO (red) and altimetry-satellites(black) taken from the red square (Figure 1), (a) North Banda Sea and (b) Flores Sea.

data dilakukan dengan metode korelasi, untuk melihat seberapa besar keeratan antara kedua data tersebut.

Data deret waktu dari tahun 20082014 hasil simulasi INDESO dan satelit altimetri (Figure 2) pada sampling box Laut Banda Utara (Laut Flores), menunjukkan korelasi yang tinggi dengan koefisien sebesar $0,92(0,88)$. Hasil uji korelasi yang tinggi menunjukkan bahwa model memiliki akurasi yang baik untuk dilakukan analisis lanjutan dan merepresentasikan kondisi yang mendekati sebenarnya pada wilayah studi. Plot tinggi paras laut hasil INDESO (hitam) dan satelit (merah) menunjukkan fluktuasi yang sama, kedua sampling box menunjukkan pola fluktuasi dominan pada periode tahunan (annual).

\section{HASIL DAN PEMBAHASAN}

\subsection{Struktur Vertikal Arlindo Banda dan Arlindo Flores}

Struktur vertikal Arlindo Banda dan Arlindo Flores secara detail dari crosssection rerata komponen arus meridional (transek A-B) dan zonal (transek C-D) dari model INDESO (2008-2014) disajikan pada Figure 3. Menurut Gordon \& Ffield (1994) bahwa karakteristik Arlindo sekitar 83\% mengalir pada lapisan termoklin di kedalaman lebih dari $200 \mathrm{~m}$. Pada transek A-B, penampang menegak Arlindo Banda ditandai dengan pola aliran ke arah selatan (warna biru) dengan besaran kecepatan maksimum $0,17 \mathrm{~m} / \mathrm{s}$.

Aliran Arlindo Banda semakin bertambah kedalaman, kecepatannya mengalami pelemahan hingga kedalaman $300 \mathrm{~m}$ sebesar $-0,08 \mathrm{~m} / \mathrm{s}$ (Figure $3 a$ ). Hal ini serupa dengan hasil program INSTAN 2004-2006 di Pintasan Lifamatola dengan kecepatan arus kurang dari $-0,1 \mathrm{~m} / \mathrm{s}$ pada kedalaman $300 \mathrm{~m}$ (Van-Aken et al., 2009). Lapisan inti Arlindo Banda memiliki ketebalan 40-150 m dengan radius diperkirakan 193,75 km.

Pada penampang melintang dari transek C-D terlihat adanya arus yang kuat disisi selatan dari penampang di wilayah $7,8^{\circ} \mathrm{LS}$ yang merupakan lapisan dari Arlindo Flores sedangkan di sisi utara $\left(6,0^{\circ} \mathrm{LS}\right)$ diduga terdapat pusaran arus (eddies) (Figure 3b). Lapisan inti Arlindo Flores 

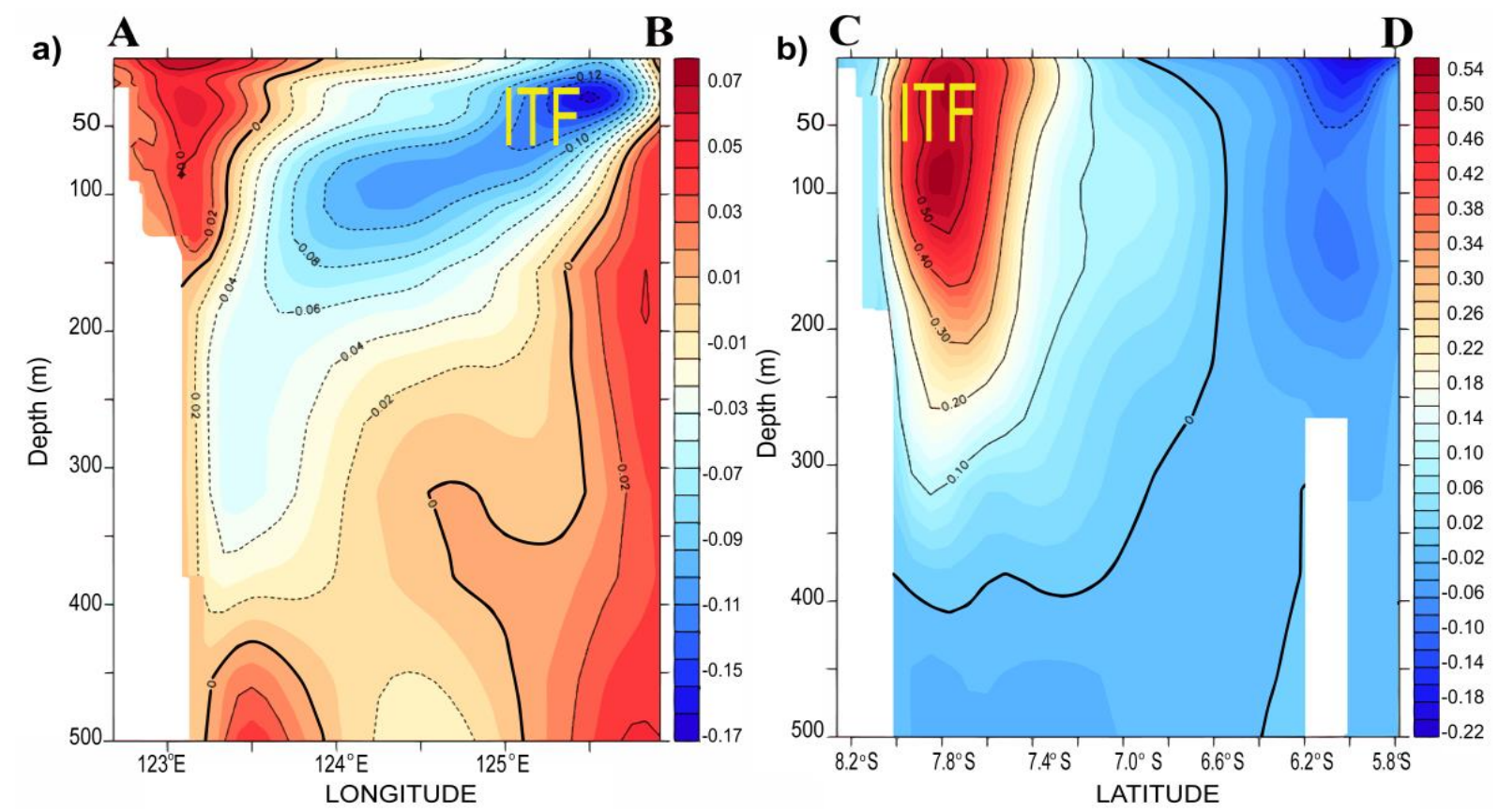

Figure 3. Structure vertical of ITF on the average component of meridional and zonal flows (2008-2014) in North Banda (a) and East Flores (b). Unit current speed $(\mathrm{m} / \mathrm{s})$; the average flow of ITF on the A-B transect to the south (blue), while from the $C-D$ transect to the east (red).

memiliki ketebalan dari permukaan hingga kedalaman $200 \mathrm{~m}$ dengan radius $111 \mathrm{~km}$. Arlindo Flores secara dominan mengalir ke arah timur dengan besaran kecepatan maksimum $0,5 \mathrm{~m} / \mathrm{s}$ (positif menuju timur). Kekuatan aliran Arlindo Flores berkurang secara bertahap hingga mencapai kedalaman $350 \mathrm{~m}$ dengan kecepatan $<0,1 \mathrm{~m} / \mathrm{s}$ (Figure $3 b)$.

\subsection{Siklus Tahunan Arlindo Banda dan Arlindo Flores}

Siklus tahunan struktur vertikal arus di wilayah kajian bervariasi berdasarkan musim, musim Barat Laut (Desember, Januari, Februari), musim Timur (Juni, Juli, Agustus), peralihan I (Maret, April, Mei), peralihan II (September, Oktober, November). Variasi musiman profil arus meridional di Banda Utara menunjukkan adanya kecepatan arus dipermukaan rerata mencapai $0,04 \mathrm{~m} / \mathrm{s}$ (ke arah utara) hingga kedalaman $40 \mathrm{~m}$ dan berikutnya arah arus konsisten bergerak ke selatan pada periode musim Barat Laut. Sebaliknya pada musim peralihan I, peralihan II dan musim Tenggara dilapisan permukaan hingga kedalaman 400 $\mathrm{m}$ arah arus dominan bergerak ke selatan. Aliran Arlindo Banda dan Arlindo Flores mengalami penguatan pada kedalaman 50$150 \mathrm{~m}$ pada musim Tenggara dan melemah pada musim Barat Laut (Figure 4a.b). Hal ini secara langsung dapat diakibatkan oleh perbedaan TPL yang bervariasi secara musiman, selama periode musim Barat Laut, tinggi paras laut mencapai minimum $(<10$ $\mathrm{cm})$. Sedangkan pada musim Tenggara maksimum sekitar $28 \mathrm{~cm}$ (Hautala et al., 2001), sehingga hal ini yang memengaruhi aliran Arlindo bergerak dari Samudra Pasifik menuju Samudra Hindia.

Profil rerata komponen arus zonal di Flores Timur pada setiap musimnya mengalami peningkatan dari permukaan hingga kedalaman $90 \mathrm{~m}$ dan dominan bergerak ke arah timur dengan rata-rata kecepatan maksimum $0,23 \mathrm{~m} / \mathrm{s}$. Besaran kecepatan arus zonal semakin melemah terhadap kedalaman 
dan mendekati 0 pada kedalaman $400 \mathrm{~m}$ (Figure 4b). Variasi musiman dari profil kecepatan arus zonal pada musim Tenggara di lapisan permukaan lebih kuat dibandingkan musim lainnya dengan kecepatan arus maksimum $1 \mathrm{~m} / \mathrm{s}$ ke arah timur. Profil arus dengan kecepatan maksimum di permukaan menunjukkan bahwa sistem arus tersebut dikendalikan oleh pengaruh angin lokal (wind-local) (Du \& Qu, 2010; Mayer et al., 2010).

Penampang menegak dari Arlindo memiliki ukuran menjadi lebih luas ketika aliran arus yang terjadi lebih kuat. Lapisan inti Arlindo secara vertikal bervariasi pada tiap musimnya (Figure 5). Pada musim Barat Laut terlihat aliran arus dilapisan permukaan bergerak ke arah utara, sementara di bawah kedalaman $50 \mathrm{~m}$ terdapat aliran bergerak ke selatan yang merupakan inti dari Arlindo Banda di wilayah $123,5^{\circ} \mathrm{BT}$ (Figure 5a). Pada musim Tenggara terlihat tegas aliran Arlindo Banda di wilayah $125,5^{\circ} \mathrm{BT}$ (Figure $5 b)$ disisi timur Laut Banda Utara dan pada musim Barat Laut terlihat di kedalaman 100 $\mathrm{m}$ sisi barat dari Laut Banda Utara (Figure
$5 b)$. Arlindo Banda lebih tegas terlihat pada musim Tenggara diakibatkan permukaan dari sisi timur dari Banda Utara merupakan saluran sempit (selat) antara Pulau Buru dan Pulau Sula sehingga ini yang menyebabkan aliran terlihat kuat ketika melewati saluran sempit dari transek Banda Utara.

Sementara itu, struktur Arlindo Flroes (Figure 6) terlihat tegas pada bulan Januari di wilayah $7,8^{\circ} \mathrm{LS}$ di kedalaman 0-50 $m$ dan pada bulan Juli berada pada kedalaman $100 \mathrm{~m}$. Menurut Sprintall et al. (2009) inti Arlindo ditemukan di lapisan permukaan dapat diakibatkan oleh pengaruh angin lokal. Angin lokal mendominasi lapisan permukaan perairan yang menggerakkan arus permukaan (Du \& Qu, 2010), pada musim Barat Laut arus dari Laut Cina Selatan bergerak melalui Laut Jawa ke Laut Flores sebagian mengarah ke utara menuju Laut Banda, begitupula sebaliknya Mayer et al. (2010). Sementara itu, pada bulan Juli (Figure 6.b) terlihat adanya aliran arus di wilayah $6,5^{\circ} \mathrm{LS}$. Aliran tersebut dapat diduga merupakan masukan dari aliran arus dari Laut Banda bagian utara.
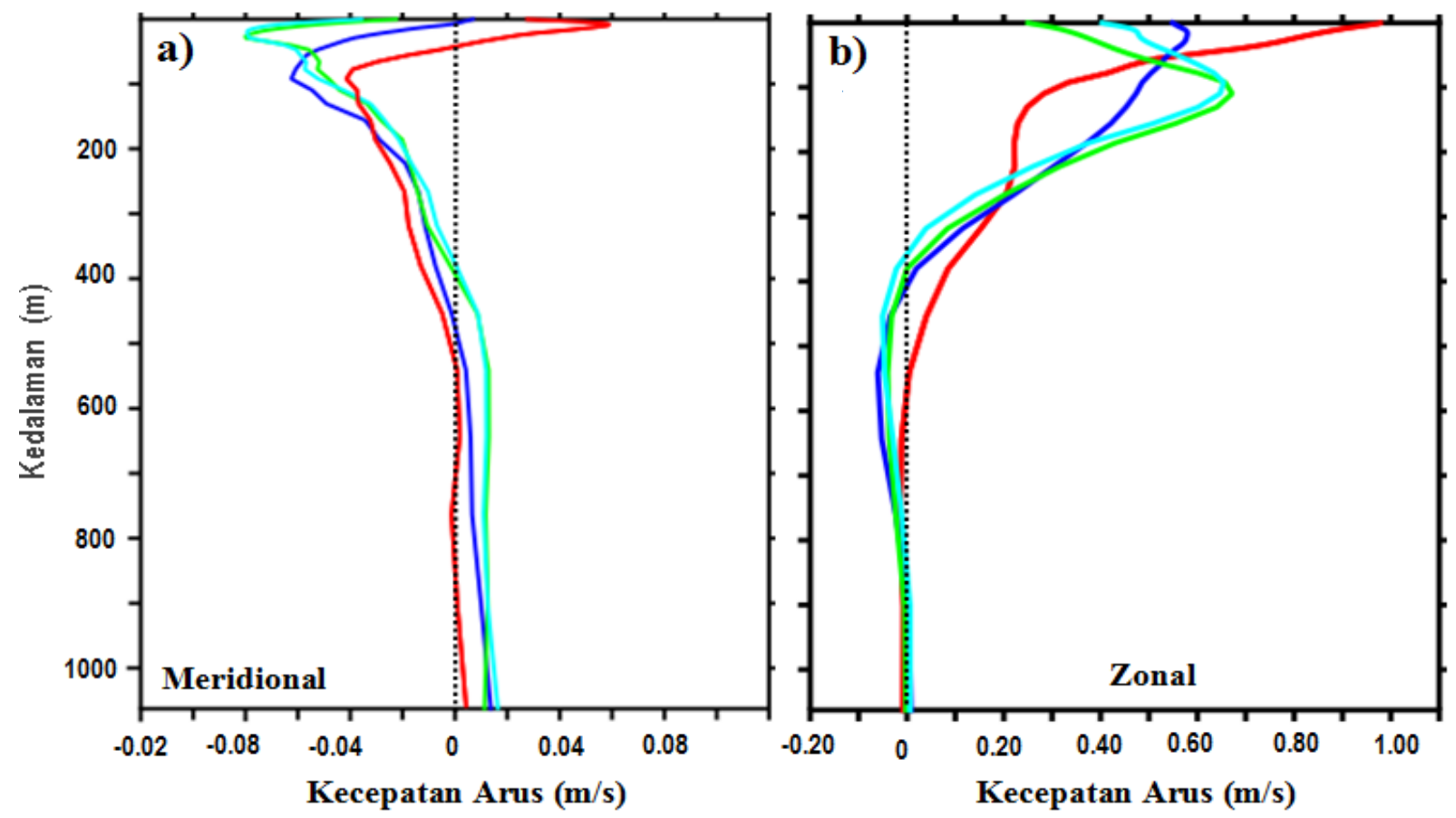

Figure 4. Vertical profiles on seasonal flows of ITF at the North Banda (a) and East Flores (b), it is based on 2008-2014 time-series data. 

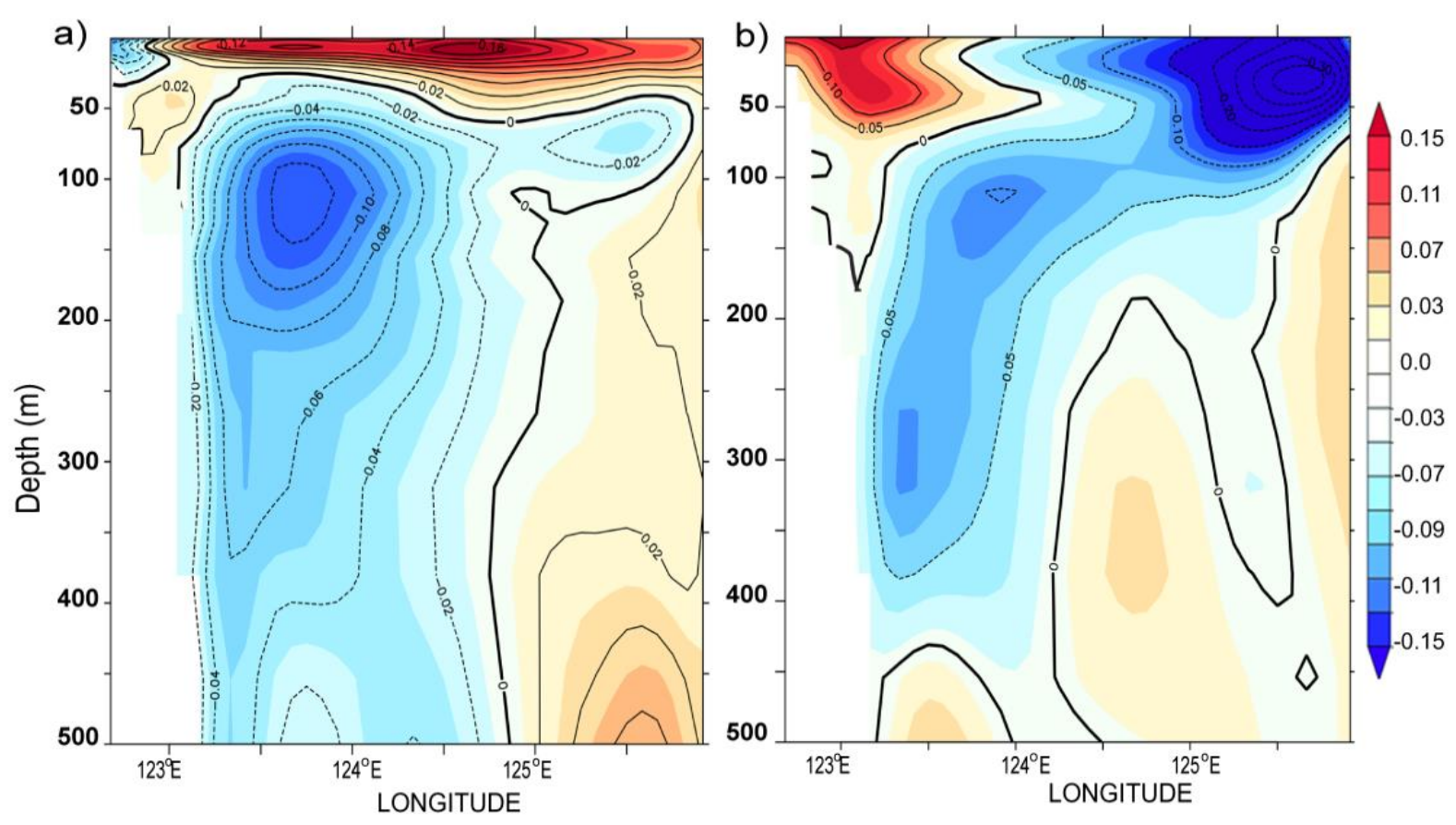

Figure 5. Seasonal variations of cross-section currents in North Banda, in the Northwest season represented in January (a) and the Southeast season represented in July (b), based on the average time-series data for 2008-2014 flows. Color degradation shows current velocity $(\mathrm{m} / \mathrm{s})$.
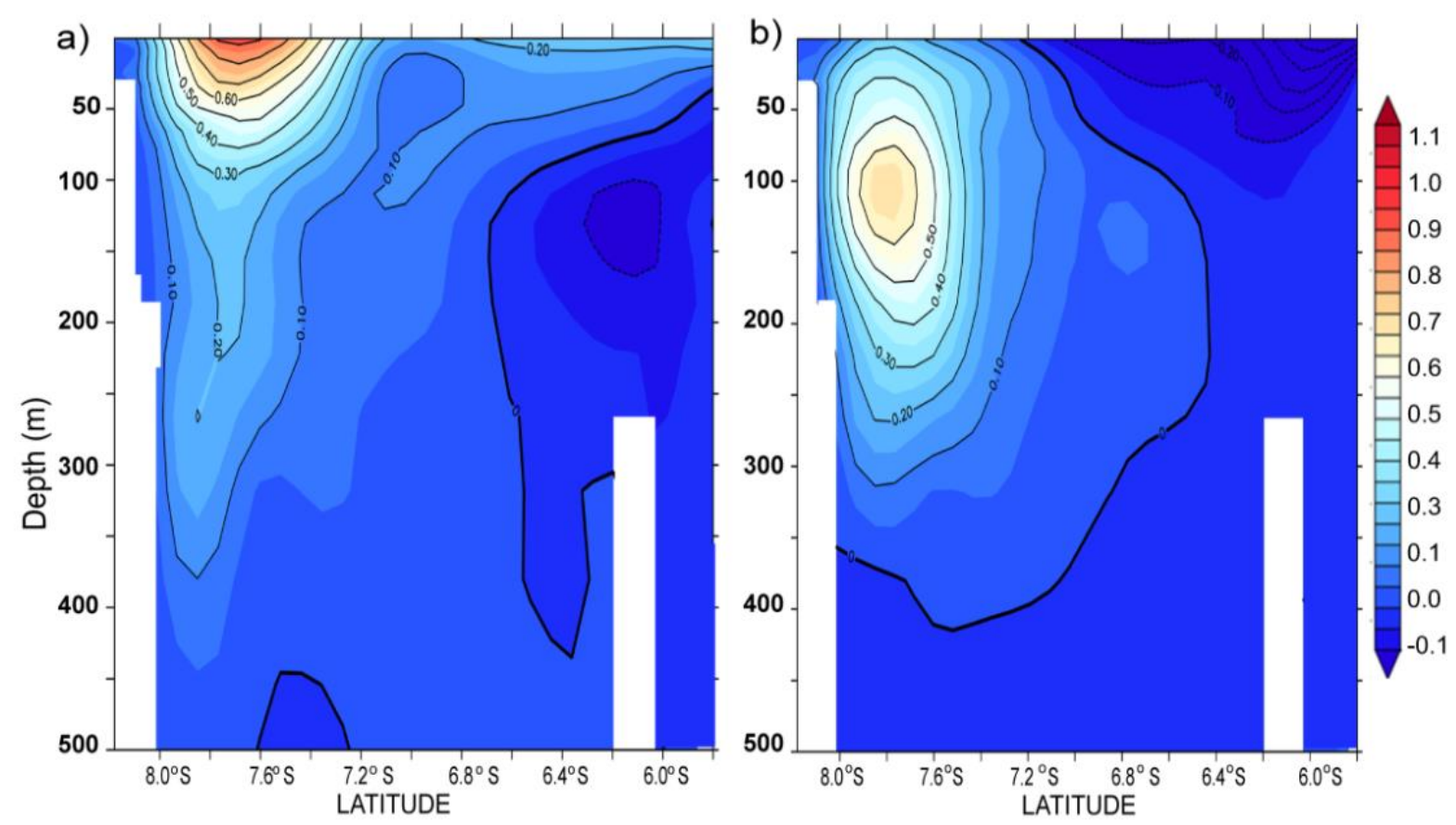

Figure 6. Seasonal variations of cross-section currents in East Flores, in the Northwest season represented in January (a) and the Southeast season represented in July (b), based on the average time-series data for 2008-2014 flows. Color degradation shows current velocity $(\mathrm{m} / \mathrm{s})$. 
3.3. Volume Transpor dan Variabilitas Arlindo Banda dan Arlindo Flores

Arlindo Banda menunjukkan transpor dengan rerata $-1,20 \mathrm{~Sv} \pm 2,43 \mathrm{~Sv}$ (Figure 7a). Transpor Arlindo Banda secara dominan bergerak ke arah selatan pada tiap musimnya dengan periode musim Barat Laut $(-3,6 \mathrm{~Sv})$ dan melemah $(-1,4 \mathrm{~Sv})$ pada periode musim Tenggara. Sementara untuk transpor Arlindo Flores secara dominan bergerak ke arah timur dengan rerata $5,07 \mathrm{~Sv} \pm 1,38 \mathrm{~Sv}$, transport maksimum pada musim Tenggara dan minimum pada periode musim Barat Laut (Figure 7c). Menurut Sprintall et al. (2009) transpor maksimum selama musim Tenggara dan minimum pada periode musim Barat Laut. Arlindo Banda mendapat inputan terbesar dari Selat Lifamatola yang berada pada kedalaman $1250 \mathrm{~m}$ dengan besaran 2,5 Sv (Van-Aken et al., 2009). Pada lapisan permukaan arah arus mengikuti arah angin dan bergerak ke Laut Maluku sebagai pintu timur Arlindo. Syamsudin et al., 2010 menemukan bahwa Arlindo Flores memiliki besaran transpor $5 \mathrm{~Sv}$ dan termasuk $50 \%$ dari aliran Arlindo Selat Makassar (11,6 Sv $\pm 3,3 \mathrm{~Sv}$ ) yang merupakan pintu utama dari Arlindo (Sprintall et al., 2009; Gordon et al., 2008).
Analisis deret-waktu dengan metode Continuous Wavelet Transform (CWT) untuk data transpor Arlindo barat Laut Banda (2008-2014), menunjukkan 3 periodesitas utama, yaitu variabilitas transpor dalam skala-waktu intra-seasonal varibility (ISV) 20-90 hari, variabilitas skala-waktu semi-annual variability (SAV) 180 hari dan variabilitas skala-waktu annual variability (AV) 360 hari (Figure 8). Pada transek A-B dari Arlindo Banda menunjukkan variabilitas transpor didominasi oleh skala waktu ISV dengan periode 20-90 hari yang membentang dari tahun 2008-2014 dengan variasi wavelet terhadap waktu cukup besar. Variasi ISV terjadi akibat fluktuasi angin musiman yang memengaruhi transpor pada lapisan permukaan (Gordon et al., 1994; Du \& Qu, 2010). Periodesitas kedua terbesar terjadi pada skala waktu musiman (SAV) dengan periode 180 hari pada rentan waktu 20112012.

Variabilitas transpor pada transek CD dari Arlindo Flores menunjukkan variabilitas transpor secara dominan pada skalawaktu tahunan (AV) yang membentang dari awal deret-waktu 2008 sampai 2014, dan beberapa secara periode terjadi pada skala ISV.

a)
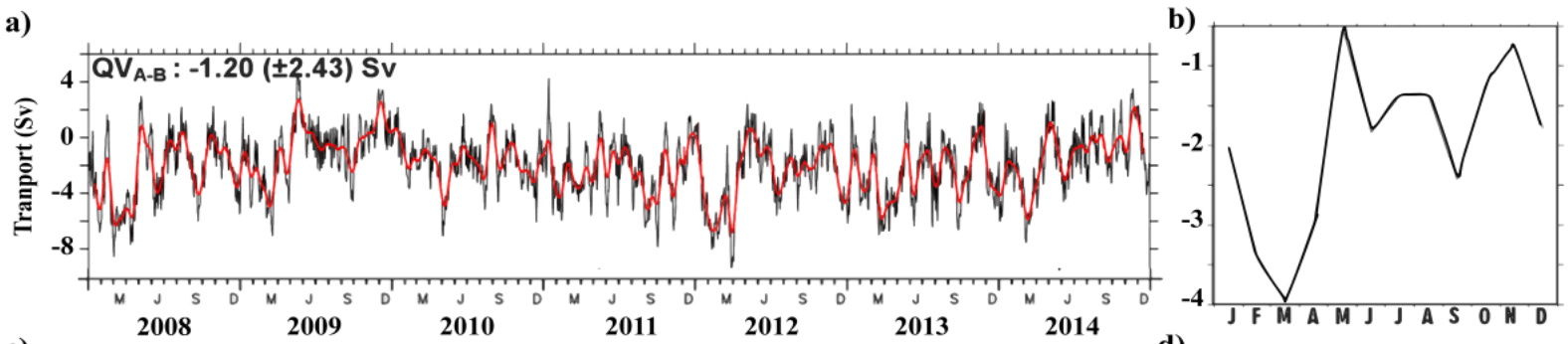

c)
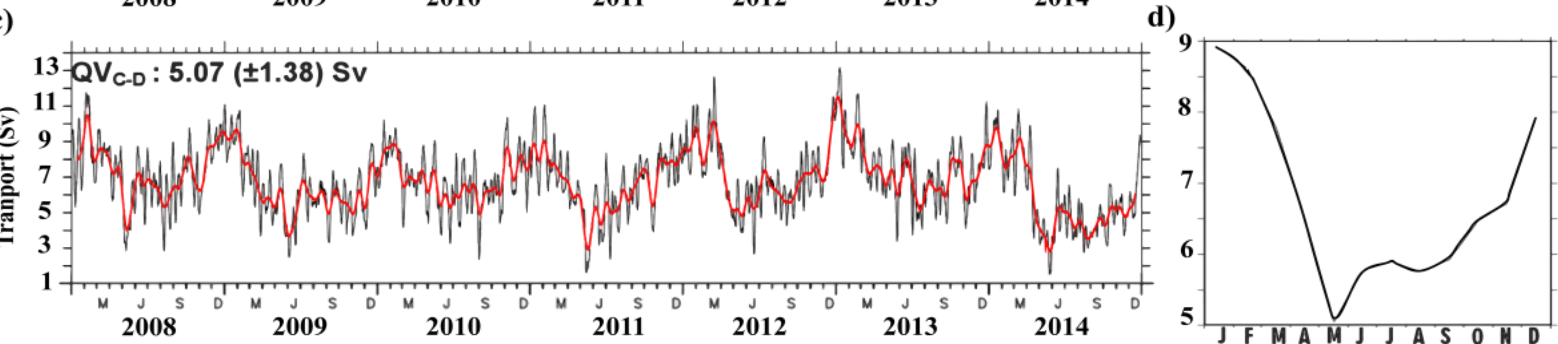

Figure 7. Volume transport time-series of the ITF (black line) on band-pass filter 31-day (red line) in North Banda (a) and the average month (b); and East Flores (c) and the average month $(d)$. 


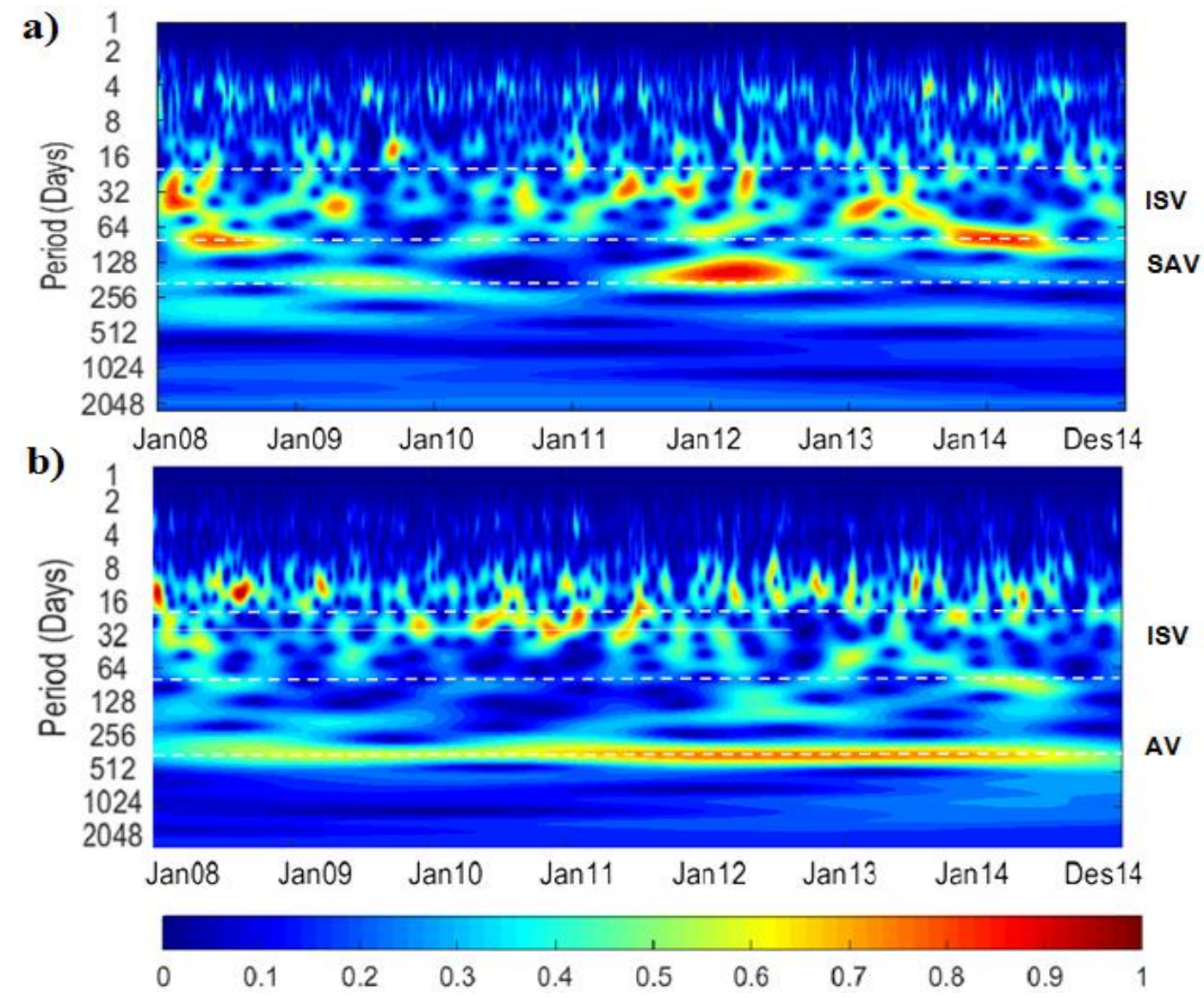

Figure 8. The results of CWT analysis of ITF transport volume in Banda sea (a) and Flores sea (b). The dashed white lines show the time-scale variability of ISV (20-90 days), SAV (180 days), and AV (360 days).

Hasil ini sejalan dengan penelitian Syamsudin et al. (2010) di Selatan Laut Banda dari Laut Flores menunjukkan adanya variasi intra-seasonal akibat dari rambatan Gelombang Kelvin yang terjadi pada periode waktu kurang dari 2 minggu. Gelombang Kelvin ini masuk ke Laut Banda melalui Selat Ombai dan Pintasan Timor yang menjalar dari Selatan Jawa-Nusa Tenggara (Sprintall et al., 2009).

\subsection{Koherensi Transpor Arlindo Banda dan Arlindo Flores}

Analisis spektral silang (cross-PSD) antar dua variabel data-deret waktu yakni arus meridional dari jalur timur Arlindo Banda dan arus zonal dari jalur barat Arlindo Flores. Analisis ini bertujuan untuk menganalisis korelasi antara fluktuasi arusdari dua jalur tersebut. Hasil analisis PSD menunjukkan nilai peak (puncak energi) signifikan terjadi pada periode antar tahunan, tahunan, semi-tahunan dan intra-musiman (Figure 9). Beberapa puncak energi spektra yang muncul di kedua deret-waktu pada periode tertentu, menunjukkan korelasi dari kedua fluktuasi deret-waktu tersebut, yang dikenal dengan koherensi (Figure 9b) dan beda fase (mendahului atau tertinggal) dari satu variabel (deret-waktu) ke variabel berikutnya (Figure 9c).

Pada skala antar-tahunan dan semitahunan, nilai koherensi tercatat masingmasing sekitar 0,88 dan 0,85 dengan beda fase sebesar 1,5 hari, dimana sinyal Arlindo Banda mendahului dari pada Arlindo Flores. Berikutnya nilai koherensi $>0,4$ pada skalawaktu ISV, 20-90 hari terjadi pada periode 
24, 46, 79 hari. Nilai koherensi tertinggi $(0,52)$ terjadi pada periode 46 hari dengan beda fase 0,07 hari. Hal ini dapat diartikan bahwa fluktuasi sinyal Arlindo Flores (periode 30 harian) muncul terlebih dahulu di transek C-D di timur Laut Flores dan kemudian $(0,6$ hari) propagasi sinyal muncul di transek A-B Laut Banda bagian utara.
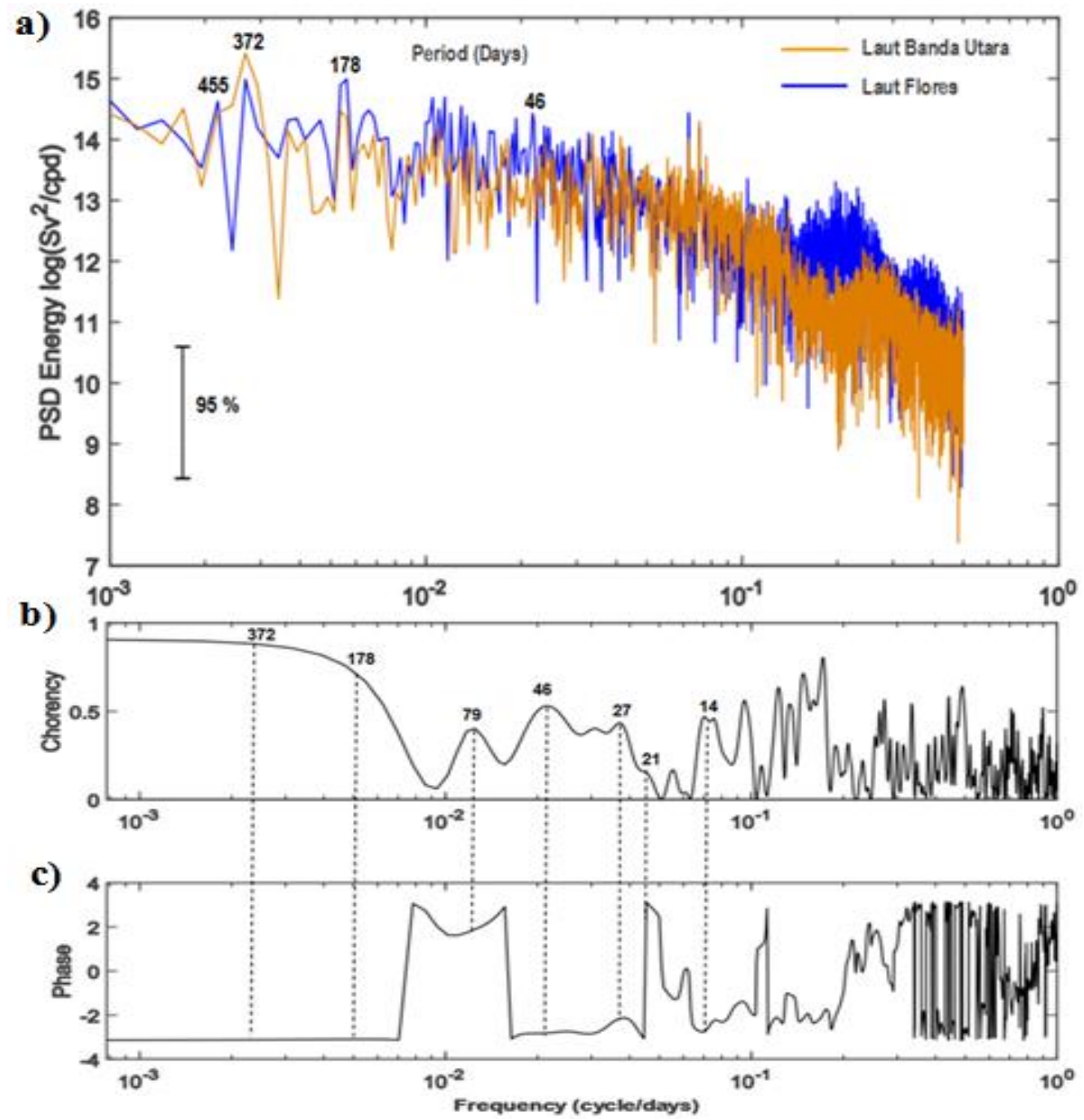

Figure 9. Cross-PSD analysis of the ITF Banda and ITF Flores (a), coherence (b) and phase (c).

Table 1. Coherence and time series phase of transport variability between the ITF Banda and ITF Flores.

\begin{tabular}{ccccc}
\hline No. & Period (days) & Time-scale & Coherency & Phase (days) \\
\hline 1 & 455 & Inter-anual & 0.88 & 1.528 \\
2 & 372 & & 0.85 & 1.176 \\
3 & 178 & Semi-Anual & 0.66 & 0.383 \\
4 & 79 & Intra-seasonal & 0.40 & 0.092 \\
5 & 46 & & 0.52 & 0.073 \\
6 & 27 & & 0.41 & 0.032 \\
7 & 14 & & 0.54 & 0.023 \\
\hline
\end{tabular}




\section{KESIMPULAN}

Laut Banda bagian barat dicirikan sebagai jalur masuk Arlindo melalui pintu barat (Laut Flores) dan pintu timur (Laut Banda Utara) dari Samudra Pasifik ke Samudra Hindia. Sumbu arus utama Arlindo Banda dominan mengalir ke arah selatan dari komponen arus meridional dan Arlindo Flores dominan mengarah ke timur dari komponen arus zonal. Struktur vertikal dari Arlindo teridentifikasi dan menguat pada kedalaman $50 \mathrm{~m}$ hingga $150 \mathrm{~m}$. Rerata transpor Arlindo Banda berkisar -1,20 Sv $( \pm 2,43 \mathrm{~Sv})$, dengan variasi tahunan transpor mencapai maksimum $(-3,6 \mathrm{~Sv})$ selama musim Barat Laut dan melemah $(-1,4 \mathrm{~Sv})$ selama musim Tenggara. Pada transpor Arlindo Flores memiliki rerata 5,07 Sv $( \pm 1,38 \mathrm{~Sv})$, dengan variasi tahunan tranpor maksimum $(8,7 \mathrm{~Sv})$ selama musim Tenggara dan melemah $(5,30 \mathrm{~Sv})$ selama musim Barat Laut. Sehingga, dengan demikian, total transpor Arlindo yang masuk ke Laut Banda bagian barat sebesar $6,27 \mathrm{~Sv}( \pm 3,81 \mathrm{~Sv})$. Variabilitas yang mendominasi dari transpor Arlindo Banda ialah periode intra-musiman (ISV) dan semi-tahunan (SAV), sedangkan variabilitas transpor Arlindo Flores didominasi oleh periode tahunan (AV).

\section{UCAPAN TERIMA KASIH}

Penulis mengucapkan terima kasih kepada berbagai pihak yang telah membantu dan memfasilitasi penelitian ini. Secara khusus penulis sampaikan terima kasih kepada pengelola program INDESO Kementerian Kelautan dan PERIKANAN (KKP) Jakarta, para Peneliti Badan Penelitian dan Observasi Laut (BPOL-KKP) di Bali dan MercatorOcéan Toulouse Prancis. Ucapan terima kasih juga kepada Reviewer yang telah memberikan masukan dalam penyempurnaan manuskrip.

\section{DAFTAR PUSTAKA}

Atmadipoera, A.S., R. Molcard, G. Madec, S. Wijffels, J. Sprintall, A. KochLarrouy, I. Jaya, \& A. Supangat. 2009. Characteristics and variability of the indonesian throughflow water at the outflow straits. Deep-Sea Research part I, 56(11): 1942-1954. https://doi.org/10.1016/j.dsr.2009.06. 004

Bendat, J.S. \& A.G. Piersol. 2010. Random data analysis and measurement procedures. 4th ed. WileyInterscience Publication, John Wiley $\&$ Sons. New York. 640 p.

Du, Y. \& T. Qu. 2010. Three inflow pathways of the Indonesian throughflow asseen from the simple ocean data assimilation. J. Dynamics of Atmospheres and Oceans, 50(2): 233-256.

https://doi.org/10.1016/j.dynatmoce.2 010.04 .001

Emery, W.J. \& R.E. Thomson. 2014. Data analysis methods in physical oceanography. Third Edition. Elsevier, Wyman Street. MA (USA). 729 pp.

Fieux, M., C. Andrie, D. Delecluse, A.G. Ilahude, A. Kartavtseff, F. Mantisi, R. Molcard, \& J.C. Swallow. 1994. Measurements within the PacificIndian oceans throughflow region. Deep-Sea Research part I, 41(7): 1091-1130.

https://doi.org/10.1016/09670637(94)90020-5

Gordon, A.L., A. Ffield, \& A.G. Ilahude. 1994. Thermocline of the Flores and Banda Seas. J. Geophysical Research, 99(18): 235-242. https://doi.org/10.1029/94JC01434

Gordon, A.L. \& R.A. Fine. 1996. Pathways of water between the pasific and indian oceans in the indonesian seas. Nature, 379(6561): 146-149. https://doi.org/10.1038/379146a0 
Gordon, A.L. \& R.D. Susanto. 2001. Banda Sea surface-layer divergence. $J$. of Ocean Dynamic, 52(1): 2-10. https://doi.org/10.1007/s10236-001-8 172-6

Gordon, A.L. 2005. Indonesian Sea. Oceanography, 18(4): 14-27. https://doi.org/10.5670/oceanog.2005 .01

Gordon. A.L., R.D. Susanto, A. Ffield, B.A. Huber, W. Pranowo, \& S. Wirasantosa. 2008. Makassar Strait throughflow, 2004 to 2006. J. Geophysical Research, 35(L24605): 1-5. https://doi.org/10.1029/2008GL0363 72

Gordon, A.L., J. Sprintall, H.M. Van-Aken, R.D. Susanto, S. Wijffels, R. Molcard, A. Ffield, W. Pranowo, \& S. Wirasantosa. 2010. The Indonesian throughflow during 2004-2006 as observed by the INSTANT program. Dynamics Atmospheres and Oceans, 50(2): 115-128.

https://doi.org/10.1016/j.dynatmoce. 2 009.12.002

Grinsted, A., J.C. Moore, \& S. Javrejeva. 2004. Apllication of cross wavelet transform and wavelet coherence to geophysical time series. Nonlinear Processes in Geophysics, 11: 561566. https://doi.org/10.5194/npg-11561-2004

Hautala, S.L., J. Sprintall, J. Potemra, A.G. Ilahude, J.C. Chong, W. Pandoe, \& N. Bray. 2001. Velocity structure and transport of the Indonesian Throughflow in the major strait restricting flow into the Indian Ocean. J. Geophysical Research, 106(19): 19527-19546. https://doi.org/10.1029/2000JC00057 7

Hutahaen, W. \& R.E. Wilson.1992. Upper Layer Circulation in the Banda Sea inResponse to the Onset Of Monsoon
Winds. Marine Research Indonesia, 28: 81-95.

https://doi.org/:10.14203/mri.v28i0.4 15

Iskandar, I., Y. Masumoto, K. Mizuno, H. Sasaki, A.K. Affandi, D. Setiabudidaya, \& F. Syamsudin. 2014. Coherent intraseasonal oceanic variations in the eastern equatorial Indian Ocean and in the Lombok and Ombai Straits from observations and a high-resolution OGCM. $J$. Geophys. Res. Ocean., 119(4449): 615-630. https://doi.org/10.1038/175238c0

Liang, L., H. Xue, \& Y. Shu. 2019. The Indonesian Throughflow and the Circulationin the Banda Sea: A Modeling Study. J. Geophysical Research: Oceans, 124: 3089-3106. https://doi.org/10.1029/2018JC01492 6

Masoleh, V.C., A.S. Atmadipoera, \& M. Purba . 2019. Ocean current signals propagation along the Outer Banda Arcs. IOP Conf. Ser. Earth Environ. Sci., 278(1): 1-7. https://doi.org/10.1088/17551315/278/1/012044

Mayer, B., P.E. Damm, T. Pohlmann, \& S. Rizal. 2010. What is driving the ITF? An illumination of the Indonesianthroughflow with a numerical nested model system. $J$. Dynamics of Atmospheres and Oceans, 50(2): 301-312. https://doi.org/10.1016/j.dynatmoce.2 010.03 .002

Quentel, E.X., M.A. Carton, M.A. Gutscer, \& R. Hoobs. 2010. Detecting and characterizing mesoscale and hydrographic measurements in the Gulf of Cadiz, J. Geophysical Research, 37(6): 1-5. https://doi.org/10.1029/2010GL0427 66

Shinoda, T., W. Han, E.J. Metzger, \& H.E. Hurlburt. 2012. Seasonal variation of 
the Indonesian throughflow in Makassar Strait. J. Phys. Oceanogr., 42(7): 1099-1123.

https://doi.org/10.1175/JPO-D-110120.1

Sprintall, J., A.L. Gordon, R. Murtugudde, \& R.D. Susanto. 2000. A semiannual Indian Ocean forced Kelvin wave observed in the Indonesian seas in May 1997. J. Geophys. Res. Ocean., 105(C7): 17217-17230. https://doi.org/10.1029/2000jc900065

Sprintall, J., S.E. Wijffels, R. Molcard, \& I. Jaya. 2009. Direct estimates of the Indonesian throughflow entering the Indian Ocean: 2004-2006. J. Geophysical Research, 114(C07001): 1-9.

https://doi.org/10.1029/2008JC00525 7

Sukresno, B. \& I.W. Kasa. 2008. Dynamical analysis of Banda Sea concerning with El-Nino, Indonesian Throughflow and Monsoon by Using Satellite Data and Numerical Model. Ecotrophic, 3(2): 87-91. https://ojs.unud.ac.id/index.php/ECO TROPHIC/article/view/2497

Syamsudin, F., H.M. Van Aken, \& A. Kaneko. 2010. Annual variation of the southern boundary current in the Banda Sea. Dynamics of Atmospheres and Oceans, 50(2): 129-139.

https://doi.org/10.1016/j.dynatmoce.2 009.12.005
Torrence, C. \& G.P. Compo. 1998. A practical guide to wavelet analysis. Bull. Am. Meteorol. Soc., 79: 61-78. http://doi.org/10.1175/15200477(1998)079<0061:APGTWA>2.0 .CO;2

Tranchant, B., G. Reffray, E. Greiner, D. Nugroho, A. Koch-Larrouy, \& P. Gaspa. 2016. Evaluation of an operational ocean modal configuration at $1 / 12^{\circ}$ spatial resolution for the Indonesian seas. Oce. Phys. Geosci. Model. Dev. Disc., 8: 6611-6668. https://doi.org/10.5194/gmdd-8-66112015

Van-Aken, H.M., I.S. Brodjonegoro, \& I. Jaya. 2009. The deep-water motion through the Lifamatola passage and its contribution to the Indonesian throughflow. Deep Sea Research part I, 56(8): 1203-1216. https://doi.org/10.1016/j.dsr.2009.02. 001

Wijffels, S.E. \& G. Meyers. 2004. An intersection of oceanic wave guides: variability in the Indonesian throughflow region. J. Phys. Oceanogr., 34: 1232-1253. https://doi.org/10.1175/15200485(2004)034<1232:AIOOWV >2.0 $\mathrm{CO} ; 2$

Received : 27 January 2020

Reviewed : 31 March 2020

Accepted : 13 August 2020 
